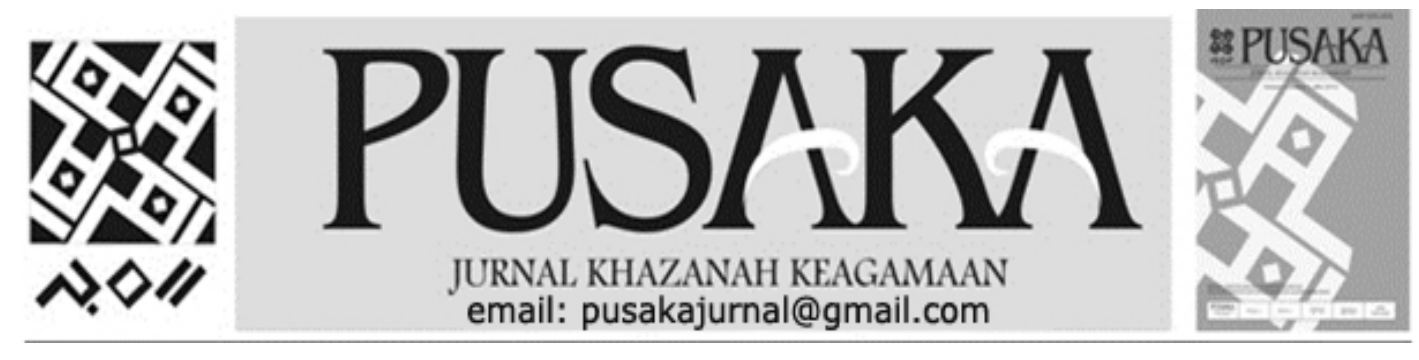

\author{
Inventarisasi Pemetaan dan Digitalisasi Naskah Klasik Di Provinsi Maluku \\ Inventory, Mapping, and Digitalization of Classical Manuscripts in Maluku
}

\title{
La Mansi
}

Balai Penelitian dan Pengembangan Agama Makassar

J1.A.P.Pettarani No.72 Makassar. Telp:0411-452952

Email: lamansilitbang@yahoo.com

\begin{tabular}{|c|c|}
\hline $\begin{array}{c}\text { Info } \\
\text { Artikel }\end{array}$ & Abstract \\
\hline $\begin{array}{c}\text { Diterima } \\
31 \\
\text { Januari } \\
2017\end{array}$ & 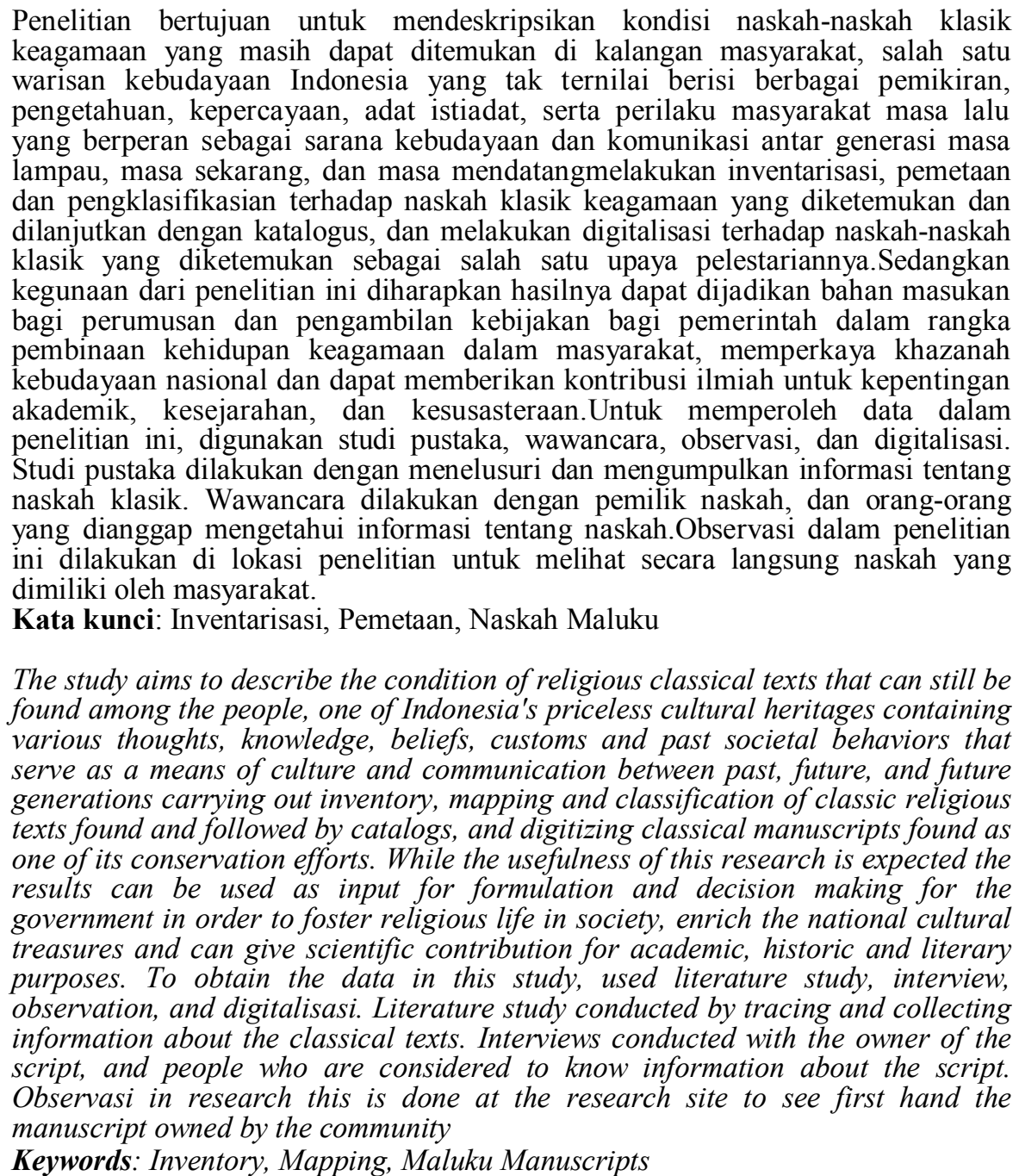 \\
\hline
\end{tabular}




\section{PENDAHULUAN}

Naskah klasik adalah salah satu warisan kebudayaan Indonesia yang tak ternilai uang, berisi berbagai pemikiran, pengetahuan, kepercayaan, adat istiadat, serta perilaku masyarakat masa lalu yang berperan sebagai sarana kebudayaan dan komunikasi antar generasi masa lampau, masa sekarang, dan masa mendatang. Tradisi penulisan berbagai dokumen dan informasi dalam bentuk naskah tulisan tangan tampaknya pernah terjadi secara besar-besaran di Indonesia pada masa lalu, terutama jika dilihat dari melimpahnya jumlah naskah yang berkaitan dengan berbagai bidang, di antaranya sastra, filsafat, adat istiadat, dan bidang keagamaan, baik yang ditulis dalam bahasa asing, maupun dalam bahasa-bahasa daerah. Melimpahnya teks teks keagamaan terutama pada unsur tasawuf, memang tidak terlalu mengherangkan terutama jika mengingat bahwa kebudayaan yang dimiliki bangsa Indonesia hingga dewasa ini secara keseluruhan merupakan hasil dari proses akulturasi manusia Indonesia (Nabilah Lubis, 2008:2).

Dalam hal naskah-naskah keagamaan Islam, tampak jumlah naskahnya lebih menonjol, terutama karena terkait dengan proses islamisasi di Indonesia yang banyak melibatkan para ulama produktif di zamannya. Data-data yang dijumpai umumnya memberi penjelasan bahwa naskah-naskah keagamaan tersebut ditulis oleh para ulama terutama dalam konteks transmisi keilmuan Islam, baik transmisi yang terjadi antara ulama MelayuNusantara dengan para ulama Timur
Tengah, maupun antara ulama Indonesia itu dengan muridmuridnya di berbagai wilayah (Masoweang, 2010:1).

Dalam konteks naskah keagamaan Islam ini, dua pola transmisi keilmuan yang terjadi di wilayah Indonesia tersebut pada gilirannya membentuk pola dua kelompok bahasa naskah: pertama naskah yang ditulis dalam bahasa Arab, dan yang kedua naskah-naskah yang ditulis dalam bahasa daerah. Dalam perkembangannya, jumlah naskah tersebut kemudian semakin membengkak dengan adanya tradisi penyalinan naskah dari waktu ke waktu, baik yang dilakukan oleh murid untuk kepentingan belajar, maupun yang dilakukan oleh "tukang salin" untuk kepentingan komersil (Massoweang, 2010: v).

Naskah-naskah klasik itu bila diinventarisasi dan diklasifikasi dengan baik kemudian disusun dalam suatu katalog menjadi sumber acuan yang sangat bernilai bagi kepentingan studi keilmuan terhadap masa lampau yang banyak sekali manfaatnya untuk berbagai kepentingan saat ini dan masa yang akan datang. Termasuk di dalamnya naskah-naskah klasik yang bernafaskan Islam, dapat mejadi sumber berharga bagi kepentingan studi keislaman dan keindonesiaan, termasuk di dalamnya studi kependidikan.

Penelitian terhadap naskahnaskah klasik keagamaan tetap mendapatkan perhatian, terutama pada akhir-akhir ini. Pelestarian naskah klasik sebagai warisan budaya dirasakan lebih tepat, lebih mudah, dan lebih bermanfaat dengan menggunakan kemajuan teknologi 
berupa digitalisasi. Karena itu, kegiatan inventarisasi, pemetaan, dan digitalisasi naskah klasik keagamaan di kawasan timur Indonesia dilakukan.

Masalah pokok dalam penelitian ini ialah bagaimana keadaan naskah klasik keagamaan di masyarakat pertama naskah ditulis dalam bahasa Arab dan kedua naskah ditulis dalam bahasa daerah.

Masalah pokok tersebut dapat dirumuskan ke dalam beberapa pertanyaan penelitian: Naskah klasik keagamaan apakah yang masih dapat diketemukan di masyarakat? Bagaimanakah penyimpanan dan pemeliharaan naskah klasik keagamaan itu yang telah dilakukan? Bagaimana cara pelestarian naskahnaskah klasik keagamaan yang baik dengan memanfaatkan keamajuan teknologi saat ini?

Tujuan penelitian adalah mendeskrepsikan kondisi naskahnaskah klasik keagamaan yang masih dapat ditemukan di kalangan masyarakat, melakukan inventarisasi, pemetaan dan pengklasifikasian terhadap naskah klasik keagamaan yang diketemukan dan dilanjutkan dengan katalog, dan melakukan digitalisasi terhadap naskah-naskah klasik yang diketemukan sebagai salah satu upaya pelestariannya. Sedangkan kegunaan dari penelitian ini diharapkan hasilnya dapat dijadikan bahan masukan bagi perumusan dan pengambilan kebijakan bagi pemerintah dalam rangka pembinaan kehidupan keagamaan dalam masyarakat, memperkaya khazanah kebudayaan nasional dan dapat memberikan kontribusi ilmiah untuk kepentingan akademik, kesejarahan, dan kesusasteraan.

Pengertian naskah klasik keagamaan yang digunakan dalam penelitian ini adalah karya tulisan tangan seperti manuskrip, buku, kumpulan tulisan dalam lembaran lepas, baik berupa tulisan asli pengarangnya, maupun salinannya yang berumur sekurang-kurangnya 50 tahun dan berhubungan dengan agama (Islam), baik yang berkaitan dengan doktrin maupun sejarahnya.

Inventarisasi adalah mencari informasi, menemukan, dan mencatat hal-hal yang berkaitan dengan naskah, di antaranya bentuk pisik naskah, bahasa dan isi naskah itu. Pemetaan naskah adalah memetakan naskah klasik berdasarkan geografis, bentuk, umur, dan isi naskah. Digitalisasi adalah proses alih media dari naskah secara pisik menjadi bentuk naskah secara digital yang tersimpan dalam bentuk soft copy dengan menggunakan kamera digital. Tradisi Tulis sangat penting artinya sebagai buah pikiran dan perasaan. Tulisan adalah perwujudan jati diri dalam masyarakat, orang Bugis, Makassar, dan Mandar di Sulawesi Selatan suku bangsa yang beruntung memiliki tradisi tulis, memiliki Naskah Tradisional yang dikenal dengan Lontara, aksara Lontara kuno dan aksara lontara Bugis (Paeni, 2003: v).

\section{Metode Penelitian}

Penelitian ini dilaksanakan di desa Kaitetu Kecamatan Laihitu kota Ambon, Kabupaten Maluku Tengah Untuk memperoleh data dalam penelitian ini, digunakan studi pustaka, wawancara, observasi, dan digitalisasi. Studi pustaka dilakukan 
dengan menelusuri dan mengumpulkan informasi tentang naskah klasik. Wawancara dilakukan dengan pemilik naskah, dan orangorang yang dianggap mengetahui informasi tentang naskah. Observasi dalam penelitian ini dilakukan untuk melihat secara langsung naskah yang dimiliki oleh masyarakat. Digitalisasi dilakukan dengan pemotretan naskah yang diperoleh dengan menggunakan kamare digital.

Dengan menggunakan pendekatan kualitatif, analisis yang digunakan dalam penelitian ini berpegang pada perinsip penelitian kualitatif, yaitu pengumpulan, pengolahan dan analisis data dilakukan secara bersamaan selama proses penelitian. Proses analisis data dimulai dengan menelaah data yang tersedia dalam berbagai sumber.

\section{PEMBAHASAN}

Maluku adalah salah satu provinsi yang ada dalam wilayah Republik Indonesia, ibukotanya adalah Ambon. Provinsi Maluku Tengah terdiri atas gugusan kepulauan yang dikenal dengan Kepulauan Maluku. Sebelum dimekarkan, provinsi ini dijuluki dengan "Daerah Seribu Pulau", karena wilayahnya terdiri dari sekitar seribu pulau. Pada tahun 1999 melalaui Undang-Undang RI Nomor 46 Tahun 1999 tertanggal 12 Oktober 1999, sebagian wilayah Provinsi Maluku dimekarkan menjadi Provinsi Maluku Utara, dengan ibukota di Sofifi (Wikipedia Bahasa Indonesia. Maluku. Online: http://id.wikipedia.org/wiki/Maluku.

Diakses tanggal 1 April 2009).

Secara geografis, Provinsi Maluku terletak di bagian selatan
Garis Khatulistiwa dengan luas wilayah seluruhnya kurang lebih $581.376 \mathrm{~km}$ persegi, terdiri atas daratan seluas $54.185 \mathrm{~km}$ persegi dan laut seluas $527.191 \mathrm{~km}$ persegi. Dengan demikian, lebih banyak wilayah Provinsi Maluku merupakan lautan, yaitu sebesar 90.7 persen dari luas keseluruhannya. Wilayah daratan Maluku terpisah oleh beberapa pulau, baik kecil maupun besar dengan jumlah 559 buah pulau. Di Maluku, terdapat beberapa pulau yang tergolong pulau besar, yang terbesar adalah Pulau Seram di Kabupaten Maluku Tengah, kemudian Pulau Buru di Kabupaten Buru, dan Pulau Yamdena di Kabupaten Maluku Tenggara Barat. Pulau-pulau yang besar lainnya adalah Pulau Ambon di Kota Ambon, Pulau Kola, Wokam, Kabror, Trangan, dan Pulau Maekor di Kabupaten Maluku Tenggara, dan Pulau Wetar di Kabupaten Maluku Tenggara Barat. Selain pulau-pulau yang besar, di Maluku terdapat pula banyak pulau-pulau yang kecil, yang sebagian besar pulau-pulau yang kecil itu tidak dihuni oleh penduduk. Sebelum datangnya imperialisme Barat ke wilayah Nusantaradi Maluku, telah beridiri tiga kerajaan, yaitu Kerajaan Huamual di Seram Barat, Kerajaan Iha di Pulau Saparua, dan Kerajaan Hitu di Jazirah Leihitu, Pulau Ambon.Kerajaan yang paling besar dan berpengaruh daripada tiga kerajaan itu adalah Kerajaan Hitu. Kerajaan Tanah Hitu mencapai kejayaannya pada masa 1470-1682, yaitu sejak rajanya yang pertama (Zainal Abidin) hingga raja yang keenam (Hunilamu). Pada periode tersebut, Kerajaan Tanah Hitu pernah 
menjadi pusat perdagangan rempahrempah yang sangat vital di kawasan Maluku.

Secara administratif, Provinsi Maluku terdiri atas 11 daerah wilayah tingkat II, sembilan wilayah berstatus kabupaten, yaitu Kabupaten Buru, Buru Selatan, Kepulauan Aru, Maluku Barat Daya, Maluku Tengah, Maluku Tenggara, Maluku Tenggara Barat, Seram Bagian Barat, dan Kabupaten Seram Bagian Timur. Sedangkan dua wilayah yang berstatus kota adalah Kota Ambon, dan Kota Tual.

Dilihat dari segi agamanya, masyarakat Maluku sangat heterogen. Hal ini disebabkan karena perubahan struktur pemerintahan sejak kemerdekaan tahun 1945, dengan bersatunya kerajaan-kerajaan yang berada di wilayah Nusantara Indonesia dalam pangkuan Negara Republik Indonesia, sangat besar pengaruhnya terhadap karena keragaman agama yang dianut oleh penduduk Maluku. Semakin terbukanya daerah ini terhadap pendatang yang ditunjang oleh sarana perhubungan yang semakin baik, menyebabkan semakin banyaknya penduduk dari luar memasukinya dan bermukim padanya. Mereka yang telah menganut berbagai agama dan memiliki budaya beranekaragam datang ke daerah ini tidak musti harus mengikuti agama dan budaya setempat. Mereka bebas memeluk agamanya dan memelihara budayanya, yang penting baginya dapat menyesuaikan diri dengan masyarakat yang didatangi. Pendatang yang paling menonjol dalam hal ini adalah para transmigran.
Menurut data Kantor Wilayah Departemen Agama Provinsi Maluku tahun 2007, prosentase jumlah penduduk Provinsi Maluku yang memeluk agama Islam sebanyak 945.617 orang $(56.7 \%)$, Kristen 592.314 orang $(35.5 \%)$, Katolik 124.872 orang $(7.5 \%)$, Hindu 3.624 orang $(0.2 \%)$, dan Budha 1.122 orang $(0.1 \%)$. Data tersebut menunjukkan bahwa lebih dari separuh penduduk Provinsi Maluku beragama Islam. Penduduk yang memeluk berbagai agama tersebut, selain penduduk asli juga para pendatang dari luar Maluku. Dua pemeluk agama yang paling besar di daerah ini ialah Islam dan Kristen.

Pelaksanaan kegiatan dan aktifitas keagamaan umat beragama pada umumnya berpusat di rumahrumah ibadah yang telah didirikan oleh penganut dan organisasi keagamaan.Jumlah rumah ibadah bagi umat Islam sebanyak 1.028 mesjid. Rumah ibadah bagi penganut Kristen berjumlah 792 gereja, bagi penganut Katolik berjumlah 242 gereja. Rumah ibadah bagi penganut Hindu berjumlah 6 buah pura. Rumah ibadah bagi penganut Budha berjumlah 10 buah wihara.

Hubungan antar umat beragama di Maluku Tengah sebelum konflik tahun 1999 adalah relative harmonis. Pada saat itu hubungan antar Muslim dengan Kristen terjain dengan baik serta terjadi pembauran pemukiman pada banyak tempat kaum Muslim dan Kristen tinggal bersama dalam satu pemukiman. Hubungan harmonis tersebut ditandai dengan salin membantu dalam pendirian rumah ibadah masing-masing, saling mengunjungi ketika hari besar agama 
Idu Fitri maupun Natal, serta beberapa hubungan sosial yang mendakan ada baik hubungan antara kedua simpatisan agama.

Konflik yang terpecah pada saat itu berawal dari hari raya Idul Fitri pada awal tahun 1999 di Ambon, tidak memerlukan waktu lama menjelar sampai ke Maluku Tengah dan wilayah yang dekat dengan Ambon. Tak lama setelah konflik Ambon meletus, konflik pun terjadi di Haruku, Saparua, Jazirah Hitu sampai wilayah Seram bagian Selatan sedangkan wilayah Seram bagian Utara relatif aman atau tak terpengaruh oleh kerusuhan.

Akses dari kerusuhan tersebut adalah dengan adanya segragasi pemukiman yang berdasarkan agama dan wilayah pemukiman yang secara segragasi antara simpatisan Muslim dan Kristen, jika di negeri pemukiman Muslim maka dipastikan tidak ada Kristen di tempat itu demikian pulah sebaliknya. Sampai hari ini segragasi pemukiman berdasarkan agama masih terjadi. Akibat segragsi pemukiman tersebut maka hubungan antara Muslim dan Kristen terbatas pada tempat saja, seperti di kantor dan pasar (Ratnawati, 2006).

\section{Gambaran Naskah Klasik}

Naskah klasik yang ada di Provinsi Maluku cukup banyak tersebar di kalangan masyarakat yang jumlahnya tidak diketahui. Sebagian naskah itu telah diinventarisir oleh beberapa lembaga yang memiliki kepedulian terhadap naskah klasik. Inventarisasi dilakukan oleh Museum Nasional, Departemen Pendidikan dan Kebudayaan dan telah ditebitkan dalam sebuah buku "Katalog Koleksi
Naskah Maluku" pada tahun 1981 (Yusuf, 2009). Katalog ini memuat informasi tentang beberapa naskah yang dikelompokkan dalam 7 macam naskah, yaitu: 1) geografi, 2) sejarah dan cerita rakyat, 3) penjanjian dan kontrak, 4) laporan catatan surat, 5) pemberitahuan dan pengangkatan, 6) bahasa dan sastera, dan 7) peta (Tjandrasasmita, 2008: 17).

Inventarisasi naskah klasik dilakukan oleh Proyek Penelitian Keagamaan Badan Litbang Agama dan Diklat Keagamaan Departemen Agama pada tahun 1995. Inventarisasi dalam bentuk penelitian difokuskan pada naskah klasik yang bernafaskan Islam di Provinsi Maluku. Penelitian tersebut telah diterbitkan dalam bentuk Katalog Naskah Klasik yang Bernafaskan Islam di Indonesia pada tahun 1998/1999. Buku tersebut telah menginventarisir sebanyak 34 buah naskah (Mulia, 1998/1999: 191-214). Naskah-naskah klasik yang bernafaskan Islam yang terinventarisir dalam katalog tersebut, antara lain: Alquran, Berzanji, Fikih, Kumpulan Ayat-Ayat Alquran, Kumpulan Hadis, Khutbah Jumat, Khutbah Hari Raya Idul Fitri, Khutbah Hari Raya Idul Adha, Mujarrabat, Matriks Penanggalan Islam, Penuntun Hari Baik, Tafsir Ayat-Ayat Alquran, Tauhid, dan Tahlilan.

Inventarisasi naskah klasik dilakukan oleh Balai Kajian Sejarah dan Nilai Tradisional Provinsi Maluku pada tahun 1998. Inventarisasi dilakukan di Kecamatan Leihitu Kabupaten Maluku Tengah. Jumlah naskah klasik yang diinventarisir sebanyak 26 buah naskah (Tim Peneliti, 1998: 4-14), dan pada umumnya naskah- 
naskah tersebut berkaitan dengan naskah agama Islam, antara lain: Alquran, Berzanji (Maulud), Rahasia Al-Fatihah, Khutbah Jumat, Matriks Penanggalan Islam, Zikir, Tauhid, Doa, dan Hikayat Nur Muhammad. Selain itu terdapat pula naskah yang berkaitan dengan sejarah, seperti Hikayat Tanah Hitu, naskah yang berkaitan dengan pembuatan rumah adat, silsilah keturunan Raja Hitu, Undang-Undang Hindia Belanda, Surat Penghargaan (Besloit), dan selebaran dalam rangka monopoli rempah-rempah di Maluku.

Penelitian Balai Penelitian dan Pengembangan Agama Makassar pada tahun 2008 menginventarisir beberapa naskah yang ada di Maluku, yaitu naskah Syair Jawi, Doa, Nur Rabbi, Hikayat Nur Muhammad, Alquran, Barzanji, Falakiyah, dan Khutbah Jumat. Pada tahun 2008, Pusat Penelitian Lektur Keagamaan Badan Litbang dan Diklat Depag melakukan inventarisasi dan digitalisasi naskah klasik dan jumlah naskah yang didigitalisasi sebanyak 16 naskah dan semua naskah yang berkaitan dengan agama Islam, yaitu: Khutbah, Tajwid, Falakiyah, Syair Jawi, Khutbah Idul Fitri, Berzanji, Doa, Fiqhi, Tauhid, Tarekat, dan Hikayat Rasul. Balai Penelitian dan Pengembangan Agama Makassar pada tahun 2009 melakukan inventarisasi dan digitalisasi terhadap 24 naskah klasik yang ditemukan pada dua kecamatan di Kabupaten Maluku Tengah. Naskah-naskah tersebut antara lain terdiri atas naskah tasawuf, kumpulan hadis, doa-doa, khutbah Jumat dan Hari Raya, fiqhi, dan tauhid.
Dari penelitian tersebut, telah teridentifikasi sekitar 109 naskah klasik, dan sebagian naskah mengalami identifikasi ulang. Semua naskah klasik tersebut adalah milik individu masyarakat yang berada dalam beberapa negeri yang ada dalam wilayah Kabupaten Maluku Tengah Provinsi Maluku, seperti Negeri Seith, Kaitetu, Hila, Wakal, Hitu, Hitumessing, Mamala, Morella, dan Negeri Tolehu. Negeri-negeri tersebut terletak di pesisir pantai Jazirah Leihitu yang merupakan negeri-negeri yang masuk dalam kekuasaan Kerajaan Tanah Hitu pada masa yang lalu. Kerajaan Tanah Hitu adalah sebuah kerajaan Islam yang terletak di Pulau Ambon. Kerajaan ini memiliki masa kejayaan antara tahun $1470 \quad 1682$, sebelum kedatangan imperialisme barat ke wilayah Nusantara. Kerajaan Islam lainnya yang pernah memiliki masa kejayaan di Maluku adalah Kerajaan Huamual di Seram Barat, dan Kerajaan Iha di Saparua.

Pengaruh datangnya agama Islam terhadap kerajaan-kerajaan di Maluku mendorong penggunaan tulisan Jawi (Arab) dan bahasa Melayu dalam menyampaikan berbagai perasaan dan buah pikiran dalam berbagai aspek kehidupan, masalah-masalah keagamaan, kemasyarakatakan, perekonomian, pemerintahan, dan lain-lain. Oleh karena itu, hampir semua naskah naskah klasik yang diperoleh di Maluku menggunakan tulisan Arab.

Sebagian besar naskah klasik di Maluku menjadi milik pribadi warga masyarakat dan merupakan warisan turun temurun dari nenek moyang mereka, dan pada umumnya pemilik naskah tersebut adalah 
marga yang memiliki kedudukan sebagai pejabat pemerintahan dan tokoh agama. Oleh karena naskahnaskah tersebut selalu berpindah tangan dari satu generasi ke generasi berikutnya sangat memprihatinkan, karena sementara mengalami proses kepunahan disebabkan pemiliknya pada umumnya tidak mengetahui cara pengawetan dan pemeliharaan. Upaya pemeliharaan dan pengawetan yang dilakukan oleh pemerintah selalu mengalami hambatan karena masyarakat pemilik naskah tidak mau memperlihatkan dan meminjamkan kepada orang lain, karena naskah tersebut dianggap sakral dan dijadikan sebagai simbol status. Selain itu, sebagian naskah telah dijual oleh pemiliknya kepada pembeli naskah yang berasal dari luar negeri.

Tetapi pemilik naskah selalu menyimpan naskah, namun sudah banyak naskah yang tidak didapati lagi. Hal itu disebabkan karena: 1) Naskah tersebut telah hancur kertasnya akibat usianya yang tua dan tidak terpelihara dengan baik. Hancurnya kertas juga disebabkan oleh karena tinta yang dipakai mengandung zat besi.

2) Naskah hilang ditinggalkan pemiliknya atau terbakar bersama tempat tinggal pemiliknya pada waktu terjadinya kekacauan RMS. Naskah-naskah di Pulau Haruku pada masa yang lampau cukup banyak di tangan masyarakat, akan tetapi setelah terjadinya pemberontakan RMS pada tahun 50-an banyak naskah milik masyarakat terbakar bersama rumah mereka, sehingga sekarang sulit ditemukan naskah.

Namun demikian, ada sebagian kecil naskah yang terpelihara dengan baik, yaitu naskah-naskah yang tersimpan di perpustakaan dan museum, misalnya naskah Hikayat Tanah Hitu yang ditulis oleh Imam Rijali pada tahun 1652. Lima tahun setelah Imam Rijali meninggal, naskah Hikayat Tanah Hitu yang telah ditulisnya diambil oleh kompeni Belanda, kemudian naskah ini dibaca dan dijadikan rujukan oleh dua penulis sejarah yang masyhur, Rumphius dan Valentijn dalam karangan masing-masing yang berkaitan dengan sejarah Maluku (Westerkamp, 1971: 65). Setelah naskah ini dibeli oleh Perpustakaan Universitas Leiden dari Nieman sekitar tahun 1907, maka naskah Hikayat Tanah Hitu menjadi salah satu dari beribu-ribu naskah klasik yang tersimpan di Universitas Leiden Belanda pada saat ini. Naskah Hikayat Tanah Hitu yang dimilki oleh masyarakat adalah naskah fotokopi dan naskah asli yang ada di Leiden. Z.J. Manusama telah mengkaji Naskah Hikayat Tanah Hitu untuk disetasinya pada tahun 1977 di Universitas Leiden (Manusama, 1977).

Ada beberapa naskah masih tetap dipakai dan dibaca oleh masyarakat, seperti Naskah Syair Jawi dibaca ketika acara pergantian atap dan kubah mesjid Tua di Desa Kaitetu. Naskah Syair Jawi berisi tujuh hal, yaitu 1) Nasehat kepada anak muda, 2) Kejadian Nabi Adam as, 3) Nasehat kepada orang jahil, 4) Mengikuti jejak sahabat Nabi saw, 5) Mati adalah kehendak Allah, 6) Percaya bahwa Allah Satu, dan 7) Perintah Wali bertakwa kepada Allah seperti yang dijelaskan Alquran dan Hadis Nabi saw. Naskah Hikayat Hasan dan Husain di Negeri Seith 
dibaca berkaitan dengan Hari Asyura (10 Muharram).

Naskah ini dibaca selama 10 malam berturut-turut sejak tanggal 1 Muharram sampai tanggal 10 Muharram. Naskah ini berisi tentang riwayat Hasan dan Husain, dua orang cucu Nabi Muhammad saw yang tewas dalam perang Karbala. Naskah Batu Alam di Negeri Seith dibuka dan dibaca sekali dalam dua tahun pada bulan Rabiul Awwal (bulan Maulud). Ukuran naskah ini lebar sekitar 10 meter. Ketika naskah ini dibuka dibentangkan dan diletakkan di loteng rumah, kemudian dibaca dari bawah. Naskah ini berisi tentang kejadian alam.

\section{Inventarisasi dan Deskripi Naskah Klasik di Provinsi Maluku}

Jumlah naskah yang ditemukan dalam penelitian ini sebanyak 63 buah naskah, dan naskah-naskah tersebut diperoleh dari 7 orang pemilik naskah di Kabupaten Maluku Tengah, yaitu: 1) Jafar Lain. Alamat: Negeri Kaitetu, Kecamatan Leihitu, 2) Husain Hatuwe. Alamat: Negeri Kaitetu, Kecamatan Leihitu, 3) Dra. Maya JaflungLateng.Alamat: Negeri Hila, Kecamatan Leihitu, 4) Rai Muda Latuconsina. Alamat: Negeri Peluw, Pulau Haruku, 5) Mahussaleh Latuponu. Alamat: Negeri Peluw, Pulau Haruku, 6) Rahman Ali Salampessi, dan 7) Amanullah Ripamole. Alamat: Negeri Kabau, Pulau Haruku.

Dilihat dari segi bentuk, naskah-naskah tersebut dibagi dalam tiga macam, yaitu naskah yang berbentuk buku (27 buah naskah), lembaran (3 buah naskah), dan naskah berbentuk lembaran yang digulung (33 buah naskah). Data tersebut menunjukkan bahwa naskah yang terbanyak ditemukan dalam penelitian ini adalah naskah yang berbentuk gulungan (52.4\%). Naskah gulungan adalah naskah yang ditulis di atas kertas yang panjangnya kurang lebih satu meter. Kertas panjang tersebut terdiri atas beberapa lembar kertas yang disambung dengan menggunakan lem dan jahitan benang. Sebagiannya disambung dengan potongan kain dengan berbagai warna, kertas panjang tersebut digulung dan disimpan dalam bambu.

Dilihat dari segi isinya, sebagian besar naskah (34 buah naskah) berisi khutbah terdiri atas khutbah Jumat, Hari Raya Idul Fitri, khutbah Hari Raya Idul Adha, khutbah nikah, dan khutbah maulid. Selain itu, naskah berisi, tarekat, doa, hikayat, akidah, fikhi, manasik haji, penanggalan, hadis, dan Alquran.

Kondisi sebagian naskah yang dilakukan inventarisasi dan digitalisasi baik, utuh, dan masih terbaca, dan sebagiannnya mulai rusak, walaupun masih dapat dibaca. Tetapi sebagiannya memperihatinkan karena kondisi naskah rusak dan sebagiannya tidak dapat dibaca lagi, bahkan ada naskah yang sudah hancur dan tidak dapat dilakukan inevenatrisasi dan digitalisasi. Bentuk dan isi naskah yang diinventarisir dapat dideskripsikan diantaranya sebagai berikut:

\section{Naskah milik Jafar Lain Naskah Khutbah Jumat}

Naskah ini diberi judul Khutbah Jumat. Penulis, waktu dan tempat tidak diketahui. Naskah berbentuk lembaran memanjang, dengan panjang kertas $100 \mathrm{~cm}$ dan 
lebar kertas $21 \mathrm{~cm}$. Lembaran panjang tersebut terdiri atas 3 lembar kertas yang disambung. Untuk menyambung lembaran kertas dijahit dengan benang berwarna putih. Panjang penulisan teks pada halaman depan dari atas ke bawah 95,5 cm, sedangkan lebar teks dari kanan ke kiri $18 \mathrm{~cm}$. Panjang penulisan teks pada halaman belakang dari atas ke bawah $83 \mathrm{~cm}$, sedangkan lebar teks dari kanan ke kiri 95,5 cm.Tebal naskah dua halaman, terdiri atas halaman depan dan halaman belakang. Tulisan terdapat pada halaman depan dan belakang. Jumlah baris pada halaman depan sebanyak 59 baris. Jumlah baris pada halaman belakang sebanyak 52 baris.Teks naskah ditulis dengan huruf Arab menggunakan bahasa Arab.Naskah ini ditulis pada kertas dluwang dengan tinta berwarna hitam. Naskah tidak bersampul, tapi naskah itu digulung kemudian disimpan dalam bambu, nomor halaman tidak tertulis, baik bagian atas maupun bagian bawah tulisan. Keadaan naskah masih baik dan tulisan masih jelas terbaca.

Naskah berisi khutbah jumat. Khutbah ini terdiri atas dua bagian, khutbah pertama dan khutbah kedua. Khutbah pertama berisi takbir, pujipujian kepada Allah, syahadat, salawat kepada Nabi saw., wasiat bertakwa kepada Allah, ayat dan hadis Nabidan doa. Khutbah kedua berisi takbir, puji-pujian kepada Allah, syahadat, salawat kepada Nabi Muhammad saw., dan doa.

\section{Naskah Husain Hatuwe al Habsyi Naskah Khutbah Jumat}

Naskah ini oleh pemiliknya diberi judul dengan Khutbah Jumat pada I hari bulan Ramadhan. Judul tersebut tertulis pada sampul naskah. Naskah ini ditulis oleh Wahabillah tanpa keterangan waktu penulisan. Naskah berbentuk buku, dengan panjang kertas $20 \mathrm{~cm}$ dan lebar kertas $16,5 \mathrm{~cm}$. Panjang penulisan teks dari atas ke bawah 14,5 cm, sedangkan lebar teks dari kanan ke kiri $11 \mathrm{~cm}$. Tebal naskah 24 halaman dan jumlah baris dalam satu halaman sebanyak 7 baris. Teks naskah ditulis dengan huruf Arab, pada umumnya menggunakan bahasa Arab kecuali pada halaman 6 terdapat satu kalimat yang berbahasa melayu yang menjelaskan bahwa isi naskah selanjutnya adalah khutbah kedua.

Naskah ini ditulis pada kertas Eropa, tanpa Watermark, dengan garis bayang halus dan tebal, dengan tinta berwarna hitam dan merah. Naskah bersampul dengan kertas HVS kwarto berwarna putih.Nomor halaman tertulis di bagian atas tulisan.Keadaan naskah sudah mulai rusak, sebagian halaman telah berlubang sehingga tulisannya kurang jelas terbaca.Hanya beberapa halaman dibagian awal yang masih baik dan tulisannya masih jelas terbaca.Naskah ini merupakan khutbah jumat yang berisi teks rukun khutbahpertama dan kedua.

\section{Naskah Manasik Haji}

Naskah inidiberi judul dengan Kitab Manasik Haji. Pemberian judul tersebut berdasarkan keterangan pada halaman akhir naskah. Penulisnya adalah Abdus Syukur Hatuwe (ayah pemilik naskah saat ini). Ditulis pada tanggal satu ramadhan tahun $1926 \mathrm{M}$ di Negeri Kaitetu. Naskah berbentuk buku, dengan panjang kertas $20 \mathrm{~cm}$ dan lebar kertas $16 \mathrm{~cm}$. Panjang 
penulisan teks dari atas ke bawah $17,5 \mathrm{~cm}$, sedangkan lebar teks dari kanan ke kiri $11 \mathrm{~cm}$. Tebal naskah 24 halaman dan jumlah baris dalam satu halaman sebanyak 7 baris. Teks naskah ditulis dengan Aksara Hijaiah, dengan menggunakan bahasa Arab dan Melayu.

Naskah ini ditulis pada kertas bergaris dengan tinta berwarna hitam. Naskah bersampul dengan kertas HVS kwarto berwarna putih. Nomor halaman tertulis di bagian atas tulisan. Keadaan naskah masih baik dan tulisannya masih jelas terbaca. Hanya saja ada halaman yang telah hilang di bagian awal. Sebab halaman awalnya langsung dimulai dengan nomor halaman 4 . Naskah ini merupakan petunjuk tentang manasik haji yang berisi keterangan tentang syarat, rukun dan wajib haji serta tatacara, adab dan doa-doa dalam pelaksanaan ibadah haji.

\section{Naskah Surah Yasin}

Naskah ini adalahSurah Yasin tulisan tangan. Penulis, waktu dan tempat penulisan naskah ini tidak diketahui. Naskah berbentuk buku, dengan panjang kertas $21 \mathrm{~cm}$ dan lebar kertas $17 \mathrm{~cm}$. Panjang penulisan teks dari atas ke bawah 16 $\mathrm{cm}$, sedangkan lebar teks dari kanan ke kiri $13 \mathrm{~cm}$. Tebal naskah 14 halaman dan jumlah baris dalam satu halaman sebanyak 11 baris. Teks naskah ditulis dengan huruf Arab menggunakan bahasa Arab kecuali pada akhir naskah terdapat keterangan tentang pemilik naskah yang berbahasa Melayu.

Naskah ini ditulis pada kertas Eropa dengan tinta berwarna hitam dan Merah. Menggunakan sampul dari karton berwarna abu-abu, dijilid dengan benang.Kurasnya hanya satu.Nomor halaman tertulis di bagian atas tulisan.Keadaan naskah sudah rusak terutama di bagian pinggir kertas, namun tulisan masih cukup jelas terbaca meskipun pada sebagian teks tintanya sudah meleleh. Naskah berisi teks Surah Yasin yang diselingi dengan salawat kepada Nabi saw. pada ayat-ayat tertentu.

\section{Naskah Maya Djaflung Lateng Naskah Alquran}

Naskah ini adalah alquran tulisan tangan. Penulis, waktu dan tempat penulisan naskah ini tidak diketahui. Naskah berbentuk buku, dengan panjang kertas $21 \mathrm{~cm}$ dan lebar kertas $17 \mathrm{~cm}$. Panjang penulisan teks dari atas ke bawah 16 $\mathrm{cm}$, sedangkan lebar teks dari kanan ke kiri $11 \mathrm{~cm}$. Tebal naskah 102 halaman dan jumlah baris dalam satu halaman sebanyak 11 baris. Teks naskah ditulis dengan Aksara Hijaiah.

Naskah ini ditulis pada kertas Eropa dengan tinta berwarna hitam dan merah. Naskah tak bersampul dengan 7 kuras yang dijahit dengan benang.Tanpa Nomor halaman. Keadaan naskah sudah tidak utuh lagi dan rusak di mana Juz 1-5 dan Juz 11-30 sudah tidak ada lagi.Yang tersisa hanya sebagian Juz 6 mulai dari awal surah al-Maidah sampai dengan akhir Juz 10. Sebagian teks masih jelas terbaca sedang sebagian lainnya sudah tidak jelas terbaca. Naskah berisi teks Alquran mulai dari awal Surah al-Maidah Juz 6 sampai dengan akhir Juz 10 Surah alTaubah. 


\section{Naskah Hikayat Nabi}

Naskah ini diberi judul Hikayat Nabi-nabi. Penulis naskah ini tidak diketahui. Waktu penulisan dinyatakan di halaman akhir bahwa ditulis pada tanggal 9 Jumadil akhirsedang tahunnya peneliti tidak bisa menentukan dengan jelas karena menggunakan angka yang tidak dikenal. Naskah berbentuk buku, dengan panjang kertas $27 \mathrm{~cm}$ dan lebar kertas $21 \mathrm{~cm}$. Panjang penulisan teks dari atas ke bawah 21 $\mathrm{cm}$, sedangkan lebar teks dari kanan ke kiri $16 \mathrm{~cm}$. Tebal naskah 248 halaman dan jumlah baris dalam satu halaman sebanyak 25 baris. Teks naskah ditulis dengan huruf Arab menggunakan bahasa Melayu. Naskah ini ditulis pada kertas Eropa dengan tinta berwarna hitam. Naskah tidak bersampul.Terdiri dari 8 kuras dijilid dengan benang. Nomor halaman tertulisdi bagian atastulisan. Keadaan naskah sudah rusak terutama di bagian tengah tulisan yang banyak berlubang dan tintanya meleleh sehingga hanya sebagian teks yang masih jelas terbaca.Naskah ini dianggap oleh pemiliknya Hikayat tanah Hitu tetapi ternyata berisitentanghikayat nabi-nabi antara lain Nabi Dawud, Yahya dan Sulaiman.

\section{Naskah Khutbah Nikah}

Naskah ini diberi judul Khutbah Nikah. Naskah ini berbentuk lembaran kertas dengan panjang kertas $55 \mathrm{~cm}$ dan lebar kertas $24 \mathrm{~cm}$. Panjang penulisan teks pada halaman I dari atas ke bawah 47 $\mathrm{cm}$, sedangkan lebar teks dari kanan ke kiri $17 \mathrm{~cm}$.Panjang penulisan teks pada halaman II dari atas ke bawah $43 \mathrm{~cm}$, sedangkan lebar teks dari kanan ke kiri $17 \mathrm{~cm}$. Naskah terdiri dari 2 lembar kertas yang disambung dengan jahitan benang putih. Jumlah baris pada halaman I sebanyak 19 baris dan pada halaman II sebanyak 17 baris. Teks naskah ditulis dengan huruf Arab, dan menggunakan bahasa Arab kecuali keterangan singkat tentang doa nikah ditulis menggunakan bahasa Melayu.

Naskah ini ditulis pada kertas yang bahannya dari serat kayu (dluwang dengan tinta hitam. Keadaan naskah mulai rusak di bagian atas dan bawah serta di bagian pinggir sehingga sebagian kecil teks yang berada di bagian atas dan bawah juga hilang namun sebagian teks lainnya masih jelas terbaca.Naskah ini dimasukkan dalam sebuah wadah khusus dari potongan bambu dengan digulung. Naskah ini berisi khutbah nikah disertai dengan doanya.

\section{Naskah Alquran}

Naskah ini adalah Alquran tulisan tangan. Penulis, waktu dan tempat penulisan naskah ini tidak diketahui. Naskah berbentuk buku, dengan panjang kertas $27 \mathrm{~cm}$ dan lebar kertas $19 \mathrm{~cm}$. Panjang penulisan teks dari atas ke bawah 19 $\mathrm{cm}$, sedangkan lebar teks dari kanan ke kiri $12 \mathrm{~cm}$. Tebal naskah 118 halaman dan jumlah baris dalam satu halaman sebanyak 15 baris. Teks naskah ditulis dengan huruf Arab.

Naskah ini ditulis pada kertas dluwang dengan tinta berwarna hitam dan merah. Naskah tidak bersampul, terdiri dari 6 kuras dan dijilid dengan benang.Nomor halaman tidak tertulis di bagian atas dan bawah tulisan.Keadaan naskah sudah sudah tidak utuh lagi dan rusak 
terutama di bagian pinggir kertas, namun tulisan masih jelas terbaca.Naskah berisi teks Alquran mulai dari juz ke-6 sampai juz ke-14. Sedang sebagian besar teks Alquran lainnya hilang.

\section{Naskah Khatib Rai Muda Latuconsina \\ Naskah Khutbah Idul Adha \\ Naskah ini diberi judul} Khutbah Idul adha. Penulisnya AlKhatib Rahman Ali Salampessy pada tanggal 9 Sya'ban $1410 \mathrm{H}$ bertepatan dengan tanggal 5 Maret 1990 Masehi di Pelauw. Naskah berbentuk lembaran memanjang, dengan panjang kertas $217 \mathrm{~cm}$ dan lebar kertas $33 \mathrm{~cm}$. Lembaran panjang tersebut terdiri atas 7 lembar kertas yang disambung. Untuk menyambung lembaran kertas itu digunakan lem. Panjang penulisan teks pada halaman depan dari atas ke bawah $215 \mathrm{~cm}$, sedangkan lebar teks dari kanan ke kiri 29,5 cm. Panjang penulisan teks pada halaman belakang dari atas ke bawah $128 \mathrm{~cm}$, sedangkan lebar teks dari kanan ke kiri 29,5 cm.Tebal naskah dua halaman, terdiri atas halaman depan dan halaman belakang. Tulisan terdapat pada halaman depan dan belakang. Jumlah baris pada halaman depan sebanyak 70 baris. Jumlah baris pada halaman belakang sebanyak 53 baris. Teks naskah ditulis dengan huruf Arab menggunakan bahasa Arab dan Melayu.

Naskah ini ditulis pada kertas manila dengan tinta spidol berwarna hitam dan merah. Naskah disambungkan dengan potongan kain berwarna kuning dengan menggunakan lem. Naskah tidak bersampul, tapi naskah itu digulung kemudian disimpan dalam bambu, nomor halaman tidak tertulis, baik bagian atas maupun bagian bawah tulisan. Keadaan naskah masih baik dan tulisan masih jelas terbaca.

Naskah merupakan salinan dari naskah aslinya yang berisi khutbah hari raya. Khutbah ini terdiri atas dua bagian, khutbah pertama dan khutbah kedua. Khutbah pertama berisi takbir, puji-pujian kepada Allah, syahadat, salawat kepada Nabi saw., wasiat bertakwa kepada Allah, ayat dan hadis Nabi berkaitan dengan ibadah haji, dan doa. Khutbah kedua berisi takbir, puji-pujian kepada Allah, syahadat, salawat kepada Nabi Muhammad saw., dan doa. Naskah ini milik Khatib Rai Muda Latuconsina di Pelauw Kec. Pulau Haruku Kab. Maluku Tengah.

\section{Naskah Khatib Lebe Bangsa Amanullah Ripamole Naskah Hikayat \\ Naskah ini diberi judul Hikayat} Nur Muhammad. Penulis Imam LebeWayla pada tahun 1997. Naskah berbentuk buku, dengan panjang kertas $29 \mathrm{~cm}$ dan lebar kertas $22 \mathrm{~cm}$. Panjang penulisan teks dari atas ke bawah $17,5 \mathrm{~cm}$, sedangkan lebar teks dari kanan ke kiri $23 \mathrm{~cm}$. Tebal naskah 122 halaman dan jumlah baris dalam satu halaman tidak tetap antara 12-14 baris. Teks naskah ditulis dengan huruf Arab menggunakan bahasa Melayu.

Naskah ini ditulis pada kertas berwarna putih dalam sebuah buku catatan berasal dari Panitia Nasional Majlis Tahkim XXXV Syarikat Islam tahun 1991 dengan tinta spidol berwarna hitam dan merah. Naskah bersampul kertas bekas kalender 
berwarna putih.Nomor halaman tertulis di bagian atas tulisan. Keadaan naskah masih baik dan tulisan masih jelas terbaca. Naskah merupakan salinan dari naskah asli yang berisi hikayat Nur Muhammad, hikayat Nabi membelah bulan, hikayat bercukur, hikayat Nabi wafat, hikayat haji dan hikayat Umar.

\section{Naskah Imam Lebe Rahman Ali Salampessy \\ Naskah Khutbah Jumat}

Naskah ini diberi judul Khutbah Jumat. Penulis, waktu dan tempat tidak diketahui. Naskah berbentuk lembaran memanjang, dengan panjang kertas $186 \mathrm{~cm}$ dan lebar kertas $25 \mathrm{~cm}$. Lembaran panjang tersebut terdiri atas 6 lembar kertas yang disambung. Untuk menyambung lembaran kertas itu digunakan lem. Panjang penulisan teks pada halaman depan dari atas ke bawah $179 \mathrm{~cm}$, sedangkan lebar teks dari kanan ke kiri 22,1 cm. Panjang penulisan teks pada halaman belakang dari atas ke bawah $140 \mathrm{~cm}$, sedangkan lebar teks dari kanan ke kiri 22,1 cm. Tebal naskah dua halaman, terdiri atas halaman depan dan halaman belakang. Tulisan terdapat pada halaman depan dan belakang. Jumlah baris pada halaman depan sebanyak 62 baris. Jumlah baris pada halaman belakang sebanyak 64 baris.Teks naskah ditulis dengan huruf Arab menggunakan bahasa Arab.

Naskah ini ditulis pada kertas manila dengan tinta spidol berwarna hitam dan merah. Naskah disambung dengan potongan kain berwarna kuning dan dijahit. Naskah tidak bersampul, tapi naskah itu digulung kemudian disimpan dalam bambu, nomor halaman tidak tertulis, baik bagian atas maupun bagian bawah tulisan. Keadaan naskah masih baik dan tulisan masih jelas terbaca.

Naskah merupakan salinan dari naskah aslinya yang berisi khutbah jumat. Khutbah ini terdiri atas dua bagian, khutbah pertama dan khutbah kedua. Khutbah pertama berisi takbir, puji-pujian kepada Allah, syahadat, salawat kepada Nabi saw., wasiat bertakwa kepada Allah, ayat dan hadis Nabi berkaitan dengan shalat dan doa. Khutbah kedua berisi takbir, puji-pujian kepada Allah, syahadat, salawat kepada Nabi Muhammad saw., dan doa.

\section{Naskah Khatib Mahussaleh Latuponu \\ Naskah Khutbah \\ Naskah ini diberi judul} Khutbah Jumat. Penulis, waktu dan tempat tidak diketahui. Naskah berbentuk lembaran memanjang, dengan panjang kertas $25,5 \mathrm{~cm}$ dan lebar kertas $21,5 \mathrm{~cm}$. Lembaran panjang tersebut terdiri atas 5 lembar kertas yang disambung. Untuk menyambung lembaran kertas itu digunakan lem. Panjang penulisan teks pada halaman depan dari atas ke bawah $125 \mathrm{~cm}$, sedangkan lebar teks dari kanan ke kiri $17 \mathrm{~cm}$. Panjang penulisan teks pada halaman belakang dari atas ke bawah $94 \mathrm{~cm}$, sedangkan lebar teks dari kanan ke kiri $17 \mathrm{~cm}$. Tebal naskah dua halaman, terdiri atas halaman depan dan halaman belakang. Tulisan terdapat pada halaman depan dan belakang. Jumlah baris pada halaman depan sebanyak 85 baris. Jumlah baris pada halaman belakang sebanyak 74 baris.Teks naskah 
ditulis dengan huru
menggunakan bahasa Arab.

Naskah ini ditulis pada kertas manila dengan tinta spidol berwarna hitam dan merah. Naskah disambung dengan potongan kain berwarna merah bermotif kembang dan dijahit. Naskah tidak bersampul, tapi naskah itu digulung kemudian disimpan dalam bambu, nomor halaman tidak tertulis, baik bagian atas maupun bagian bawah tulisan. Keadaan naskah masih baik dan tulisan masih jelas terbaca.

Naskah merupakan salinan dari naskah aslinya yang berisi khutbah jumat. Khutbah ini terdiri atas dua bagian, khutbah pertama dan khutbah kedua. Khutbah pertama berisi takbir, puji-pujian kepada Allah, syahadat, salawat kepada Nabi saw., wasiat bertakwa kepada Allah, ayat dan hadis Nabidan doa. Khutbah kedua berisi takbir, puji-pujian kepada Allah, syahadat, salawat kepada Nabi Muhammad saw., dan doa.

\section{Digitalisasi Naskah Klasik}

Seluruh naskah yang ditemukan sebanyak 63 buah naskah telah dilakukan pemotretan sebagai proses alih media dari naskah secara pisik menjadi bentuk naskah secara digital yang dapat dilihat dilihat dan dibaca melalui layar komputer atau monitor. Pemotretan dilakukan dengan menggunakan kamera digital Canon.

Hasil pemotretan seluruh naskah telah disimpan dalam 65 folders yang menghimpun sebanyak 1.565 files sebesar 14.6 GB (15.704.611.313 bytes). Untuk sementara, seluruh files dari hasil pemotretan disimpan dalam hardisk eksternal.

\section{PENUTUP}

Naskah klasik yang ada di Provinsi Maluku diperkirakan masih cukup banyak tersebar di kalangan masyarakat yang jumlahnya tidak diketahui, dan naskah-naskah itu merupakan milik pribadi warga masyarakat. Kondisi sebagian naskah klasik sangat memprihatinkan, karena sementara mengalami proses kepunahan disebabkan pemiliknya pada umumnya tidak mengetahui cara pengawetan dan pemeliharaan. Naskah klasik yang diinventarisasi dan didigitalisasi sebanyak 63 buah yang diperoleh dari tujuh orang pemilik naskah. Untuk sementara, seluruh files dari hasil pemotretan disimpan dalam hardisk eksternal. Perlu dilanjutkan inventarisasi dan digitalisasi naskah klasik, karena masih banyak naskah disimpan oleh masyarakat. Perlu dilakukan sosialisasi usaha pemeliharaan naskah terhadap pemilik naskah, disebabkan pada umumnya pemilik naskah tidak mengetahui cara pengawetan dan pemeliharaan. Perlu dilakukan konservasi naskah terhadap naskah-naskah milik masyarakat yang telah mengalami kerusakan. Hasil pemotretan naskah yang tersimpan dalam hardisk perlu dilakukan pengolahan dan editing dengan menggunakan program yang terbaru untuk bisa ditampilkan dan dibaca dengan baik sehingga memperoleh hasil yang maksimal. Untuk mengetahui isi dan kandungan naskah secara terperinci perlu dilakukan pengkajian dan analisis teks terhadap naskah-naskah yang telah diinventarisasi dan didigitalisasi. 


\section{DAFTAR PUSTAKA}

Lubis, Nabilah. Naskah, Teks, dan Metode Penelitian Filologi. Jakarta: Forum Kajian Bahasa dan Sastera Arab Fakultas Adab IAIN Syarif Hidayatullah, 1996.

Maluku. Online: http: //id. wikipedia. org/ wiki/Maluku. Diakses tanggal 1 April 2009).

Manusama, Z.J. Hikayat Tanah Hitu: Historie en Sociale Structure van de Amonsche Eilanden in het Algemeen en van uli Hitu in ket Bijzonder tat ket Midden der Zevertiande Eeuw, Disertasi, Leiden: Rijks Universiteit, 1977.

Massoweang Abd. Kadir dkk, Inpengtarisasi, Pemetaan dan Digitalisasi Naskah klasik, Cet. I oleh CV Indobis, Pn. Balai Penelitian dan Pengembangan Agama Makassar. 2010.

Mulia, Musda. dkk. (ed.). 1998/1999. Katalog Naskah Klasik yang Bernafaskan Islam di Indonesia.Jilid II.Jakarta: Badan Penelitian dan Pengembangan Agama, Departemen Agama RI.

Paeni, Mukhlis, dkk. 2003. Katalog Induk Naskah naskah Nusantara Sulawesi Selatan.

Ratnawati, Tri. 2006. Maluku dalam Catatan Seorang Peneliti. Yogyakarta: Pustaka Pelajar.

Tim Peneliti. Laporan Inventarisasi Naskah Klasik di Kecamatan Leihitu Kabupaten Maluku Tengah. Ambon: Balai Kajian Sejarah dan Nilai Tradisional,
Direktorat Jeneral Kebudayaan, Departemen Pendidikan dan Kebudayaan, 1998.

Tjandrasasmita, Uka. Penggunaan Tulisan Jawi di Indonesia Setelah Kedatangan Islam.Dalam Jurnal Lektur Keagamaan. Vol 6 No. 1, 2008, h, 17

Westerkamp, B. 1971. Safararrijali. Dalam CPR. Luhulimja (ed.) Bunga Rampai Sejarah Maluku. Lembaga Research Kebudayaan Nasional.

Yusuf, Yumsari. Katalog Koleksi Naskah Maluku. Onlione. http://books.Google. com/ books?. Disakse pada tanggal 9 Pebruari 2009. 